Bau Mene

Masuknya Islam di Kabupaten Fakfak

\title{
MASUKNYA ISLAM DI KABUPATEN FAKFAK DAN TINGGALAN ARKEOLOGINYA
}

\section{Bau Mene}

(Balai Arkeologi Jayapura, balar_jpr@yahoo.co.id)

\begin{abstract}
The process of introduction of Islam in Fakfak conected the sultanate of Ternate and Tidore, the two regions into the arena of the struggle for the imperial influence. The purpose of this study to determine the entry and development of the Islamic religion, form of early settlement patterns of Islam in Fakfak, the influence of foreign cultures on the archaeological remains found. This study used a qualitative descriptive approach. Research found mosques, tombs, palaces of kings and the Quran.
\end{abstract}

Key words: Islam, Fakfak, Archaeological remains

\begin{abstract}
Abstrak
Proses masuknya agama Islam di Kabupaten Fakfak tidak terlepas dari kesultanan Ternate dan Tidore, kedua wilayah tersebut menjadi ajang perebutan pengaruh kesultanan tersebut. Tujuan penelitian ini untuk mengetahui proses masuk dan berkembangnya agama Islam, bentuk pola pemukiman awal masuknya Islam di Kabupaten Fakfak, pengaruh budaya luar pada tinggalan arkeologi yang ditemukan. Penelitian ini menggunakan pendekatan deskriptif kualitatif. Penelitian yang dilakukan pada Distrik Fakfak Kota, Fakfak Barat dan Fakfak Tengah ditemukan masjid, makam, istana raja dan alquran.
\end{abstract}

Kata kunci: Islam, Fakfak, tinggalan arkeologi

\section{Latar Belakang}

Kabupaten Fakfak salah satu kabupaten di Provinsi Papua Barat yang memiliki tinggalan arkeologi yang cukup beragam. Mulai dari jaman prasejarah, hingga 


\begin{tabular}{|c|}
\hline Bau Mene \\
Masuknya Islam di Kabupaten Fakfak \\
\hline
\end{tabular}

masuknya pengaruh Islam dan Eropa. Masuknya bangsa Eropa menandai dimulainya periode kolonial di Papua. Pada tahun 1996 tim dari Balai Arkeologi Jayapura melakukan penelitian peninggalan Islam di Kecamatan Kokas. Pada penelitian tersebut berhasil didata sebuah masjid di Kampung Serarni Kelurahan Genefa Kecamatan Teluk Arguni yang berbatasan dengan Kecamatan Kokas. Hasil observasi di Desa Darembang dan Desa Furir ditemukan fragmen gerabah hias dan polos serta keramik asing yang diperkirakan berasal dari Cina dan Eropa lewat perdagangan inter-insuler.

Pada tahun 1998, tim dari Balai Arkeologi Jayapura melakukan penelitian peninggalan Islam di Kecamatan Kaimana Kabupaten Fakfak (sekarang Kecamatan Kaimana masuk dalam Kabupaten Kaimana). Dalam penelitian tersebut berhasil didata peninggalan masa Islam diantaranya kompleks Makam Raja Seran dan keluarganya, masjid, songkok raja Naro (Raja Seran ke-7) dan sejarah lisan Islam. Sementara itu, di Pulau Namatota ditemukan kompleks makam raja Namatota dan keluarganya, tembikar polos, serta tongkat (cis) yang dipergunakan imam masjid (Tim Peneliti, 2002).

Pada tahun 1999 tim dari Balai Arkeologi Jayapura mengadakan penelitian peninggalan arkeologi Islam di Kecamatan Fakfak kota. Data yang berhasil dikumpulkan terdiri dari peninggalan kerajaan Ati-ati berupa tanda raja Ati-ati, songkok raja, masjid (sudah dipugar), gong terbuat dari bahan besi, tempat sirih pinang terbuat dari tembaga, alat musik rebhana (enam buah) sedangkan dari masa kerajaan Fatagar tinggalannya berupa makam raja Fatagar dan masjid.

Di Kabupaten Fakfak terdapat beberapa kerajaan-kerajaan Islam yang berkuasa, diantaranya; kerajaan Ati-ati, Fatagar, Rumbati, Namatota, Kaimana, Ugar, Patipi. Kerajaan-kerajaan tersebut tersebar pada beberapa tempat di wilayah Fakfak. Adapun kerajaan kerajaan Rumbati, Namatota, Kaimana, Ugar sekarang masuk dalam wilayah Kabupaten Kaimana.

Berdasarkan latar belakang yang dikemukakan diatas ada tiga permasalahan yang akan diungkapkan yaitu proses masuk dan berkembangnya agama Islam di Kabupaten Fakfak, bentuk pola pemukiman awal masuknya Islam, dan pengaruh budaya luar pada tinggalan arkeologi yang ditemukan.

Secara geografis Papua memiliki kedekatan relasi etnik dan kebudayaan dengan Maluku. Dalam hal ini Fakfak memiliki kedekatan dengan Maluku Tengah, tenggara dan selatan, sedangkan dengan Raja Ampat memiliki kedekatan dengan Maluku Utara. Oleh karena itu, dalam membahas sejarah masuknya Islam ke Fakfak 


\begin{tabular}{c} 
Bau Mene \\
Masuknya Islam di Kabupaten Fakfak \\
\hline
\end{tabular}

kedua alur komunikasi dan relasi ini perlu ditelusuri mengingat warga masyarakat baik di Semenanjung Onin Fakfak maupun Raja Ampat di Sorong, keduanya telah lama menjadi wilayah ajang perebutan pengaruh kekuasaan antara dua buah kesultanan atau kerajaan besar di Maluku Utara (Kesultanan Ternate dan Tidore). Dari catatan sejarah Papua diketahui bahwa Kesultanan Tidore dominasi yang besar di pesisir pantai kepulauan Raja Ampat dan Semenanjung Onin Fakfak (Onim, 2006).

Masuknya agama Islam di wilayah pesisir akhirnya terbentuk pemukimanpemukiman Islam pada wilayah ini. Usaha untuk mengetahui pemukiman dalam suatu situs, selalu berkaitan dengan daerah hunian yang merupakan tempat manusia bertempat tinggal dan melakukan segala kegiatan hidupnya sehari-hari (Siswanto, 2009:4).

Tujuan penelitian ini untuk mengetahui proses masuk dan berkembangnya agama Islam, bentuk pola pemukiman awal masuknya Islam di Kabupaten Fakfak, pengaruh budaya luar pada tinggalan arkeologi yang ditemukan. Metode pengumpulan data dilakukan dalam beberapa tahapan yaitu (1) studi pustaka (2) survei dan (3) wawancara. Metode pengolahan data dilakukan dengan cara mendeskripsikan semua temuan kemudian dianalisis dan selanjutnya tahap penarikan kesimpulan.

\section{Pembahasan}

Survei dilakukan pada tiga distrik yaitu Distrik Fakfak Tengah, Distrik Fakfak Barat dan Distrik Fakfak Kota. Tinggalan arkeologi di Kampung Danaweria yaitu, makam raja Fatagar, lokasi istana raja Fatagar, lokasi pelabuhan. Masjid diberi nama masjid An-Nur Merapi, tetapi lebih dikenal dengan sebutan masjid Merapi, masjid terletak di Jalan Warap Made, Kampung Merapi, menghadap ke timur, lokasi masjid berdekatan dengan kompleks makam Raja Fatagar, masjid ini dibangun oleh raja Fatagar. Bangunan masjid sudah mengalami perbaikan sehingga ukuran aslinya tidak dapat diketahui secara pasti.

Bangunan utama masjid berbentuk bujur sangkar dengan ukuran panjang 10 $\mathrm{m}$ dan lebar $10 \mathrm{~m}$, pintu masuk berjumlah lima buah, tiga buah terdapat pada bagian depan, satu di samping kiri dan satu di samping kanan. Pada bagian depan diatas jendelan terdapat ventilasi udara berbentuk segi empat bersusun dengan bentuk segi tiga, ventilasi tersebut terdapat pada bagian depan tiga buah dengan ukuran yang besar 


\begin{tabular}{c} 
Bau Mene \\
Masuknya Islam di Kabupaten Fakfak \\
\hline
\end{tabular}

bagian sebelah kiri dan kanan masjid terdapat dua buah. Pada ruang utama terdapat empat buah tiang yang berfungsi sebagai tiang penyangga. Sekeliling masjid terdapat teras yang dikelilingi oleh tembok setinggi $60 \mathrm{~cm}$, diatas tembok berdiri tiang yang berfungsi sebagai tiang penyangga jumlah tiang sebanyak 16 buah.

Masjid Merapi beratap tumpang tiga, menggunakan bahan dari seng. Antara atap tumpang yang satu dengan atap yang lainnya menggunakan kayu sebagai penutup. Bagian dalam atap dipasang plafon sehingga tidak kelihatan konstruksi atapnya. Bagian dalam masjid terdapat mihrab yang digunakan imam untuk memimpin shalat berjamaah, pada bagian sebelah kanan mihrab terdapat mimbar untuk khotbah shalat jumat atau shalat pada hari-hari raya Islam.

Masjid Merapi dibangun pada tahun 1883 oleh raja Fatagar, bagian depan pintu utama masjid terdapat tulisan angka tahun 1883, 1901, 1929, 1960, dan 1975. Angka tahun yang pertama yaitu 1883 adalah angka tahun pelaksanaan pembangunan dan untuk angka-angka tahun selanjutnya adalah pelaksanaan renovasi.

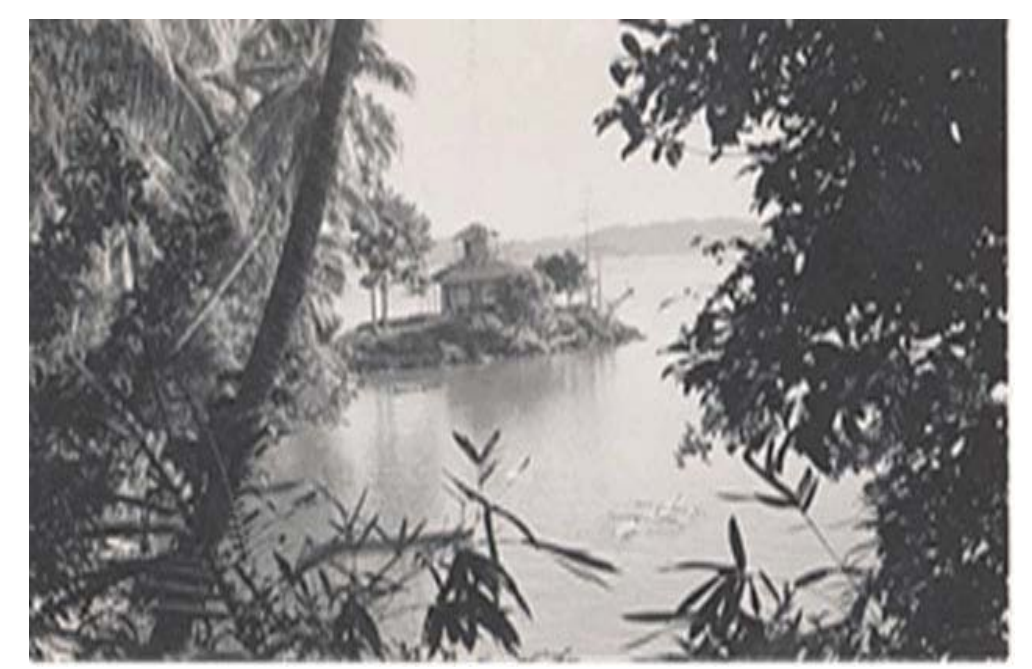

Foto 1. Masjid Merapi sebelum dipugar (sumber: google.com)

Bagian luar bangunan utama masjid sebelah kiri terdapat bedug. Berbentuk bulat terbuat dari batang pohon kelapa, yang dilubangi dan pada bagian atas terdapat bidang pukul yang ditutupi dengan kulit binatang yang terbuat dari kulit kambing. Ukuran bedug tinggi $70 \mathrm{~cm}$ diameter bagian atas yang diberi penutup kulit kambing adalah 45 $\mathrm{cm}$. 


\begin{tabular}{|c|}
\hline Bau Mene \\
Masuknya Islam di Kabupaten Fakfak \\
\hline
\end{tabular}

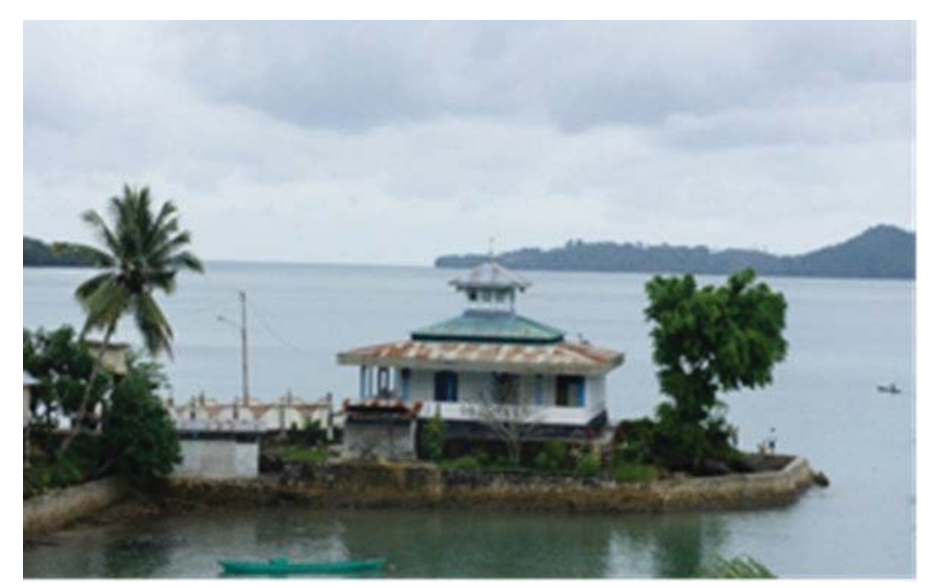

Foto 2. Masjid Merapi setelah dipugar

Awalnya Raja Fatagar membangun surau tidak jauh dari lokasi masjid yang sekarang, bekas lokasi dibangun surau terletak di Jalan Warap Made sekitar 200 meter dari masjid yang ada sekarang. Pada lokasi ini tidak ditemukan bekas atau sisa-sisa bangunan karena bangunan surau terbuat dari kayu yang bahannya mudah rusak, alasan dibangun masjid di tempat yang baru karena orang-orang yang akan melakukan sholat berjamaah semakin banyak sehingga surau tidak bisa lagi menampung jumlah.

Pada bagian sebelah timur sekitar 47 meter dari masjid terdapat makam keluarga raja Fatagar. Kompleks makam berbentuk persegi empat adapun ukuran kompleks makam panjangnya 7,92 meter dan lebar 4,94 meter. Kompleks makam dikelilingi oleh pagar besi. Nisan yang digunakan dalam kompleks makam tersebut terbuat dari kayu dengan tulisan arab.

Adapun nama-nama yang dimakamkan dalam kompleks makam tersebut sudah tidak bisa terbaca karena kayu yang dipergunakan sebagai nisan sudah lapuk bahkan ada beberapa makam yang menggunakan nisan baru karena makam tersebut digali lagi digunakan untuk keluarga raja yang baru meninggal sehingga nama yang nampak pada nisan adalah nama orang yang baru dimakamkan.

Raja Fatagar I dan raja Fatagar II dimakamkan dalam kompleks makam, tetapi di atas makam kedua raja sudah dipasang nisan baru yang menandakan bahwa nama yang tertera pada nisan baru adalah nama orang yang dimakamkan pada tempat yang sama. Pada bagian luar pagar terdapat makam kerabat raja dan imam masjid, tidak 


\begin{tabular}{c} 
Bau Mene \\
Masuknya Islam di Kabupaten Fakfak \\
\hline
\end{tabular}

dilakukan pengukuran terhadap makam maupun nisan karena nisan yang ada pada kompleks makam tersebut adalah nisan yang baru, nisan yang lama sudah rusak karena terbuat dari kayu. Tidak terdapat jirat ataupun cungkup pada makam-makam yang ditemukan.

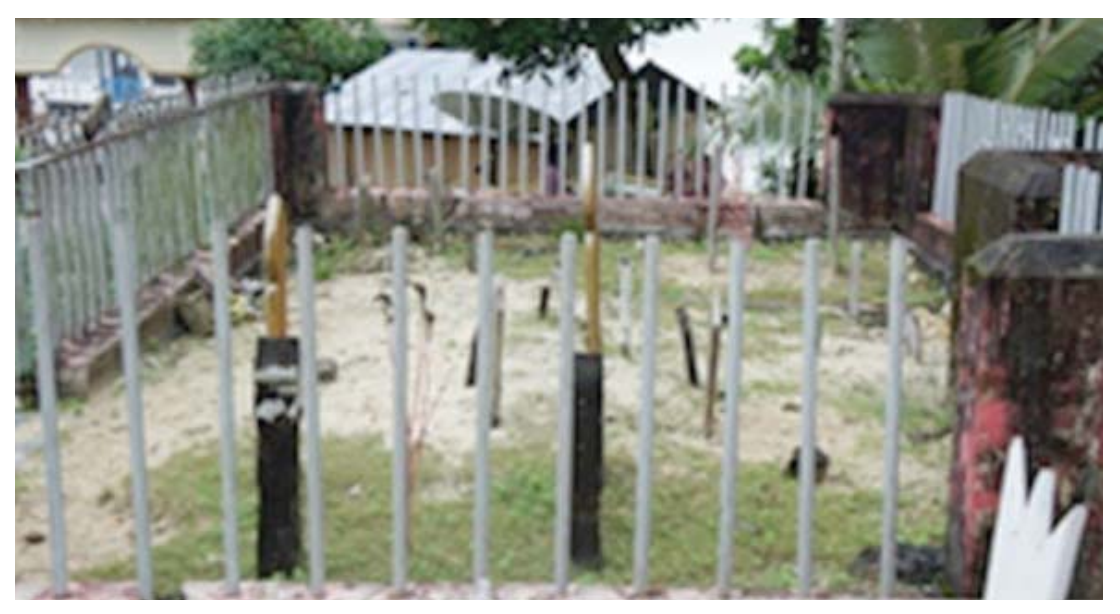

Foto 3. Kompleks makam raja Fatagar

Sekitar 100 meter ke arah selatan terdapat tanah bekas bangunan tempat tinggal raja Fatagar. Bangunan rumah maupun sisa-sisanya tidak dapat ditemukan lagi karena rumahnya terbuat dari bahan kayu yang mudah rusak sehingga tidak bisa bertahan lama informasi keberadaan tanah bekas bangunan tempat tinggal raja tersebut diperoleh dari masyarakat sekitar. Penggunaan kayu dalam pembuatan bangunan rumah disebabkan kayu mudah diperoleh pada lingkungan sekitar. Pada bagian sebelah utara masjid kurang lebih $300 \mathrm{~m}$ terdapat bekas pelabuhan lama. Pelabuhan terletak antara Pulau Tuber Seram dan Pulau Kei-kei, tidak dilakukan pengukuran karena sisa-sisa pelabuhan sudah tidak dapat disaksikan disebabkan pelabuhan tersebut terbuat dari kayu yang mudah rusak, selain itu akses menuju bekas pelabuhan pada saat penelitian tidak ada.

Pada Distrik Fakfak Kota di kawasan wilayah pantai raja ditemukan bangunan rumah tempat tinggal raja, makam keluarga raja Fatagar dan bangunan masjid yang dibangun oleh raja Fatagar. Masjid pada awalnya berupa surau yang terbuat dari kayu yang mudah rusak, bentuk dan konstruksi aslinya sudah tidak kelihatan. Bangunan tempat tinggal raja terletak pada bagian selatan masjid terletak di Jalan Izak telussa, bangunan masih digunakan oleh keturunan raja dan keluarganya. Bentuk bangunan 


\begin{tabular}{c|}
\hline Bau Mene \\
Masuknya Islam di Kabupaten Fakfak \\
\hline
\end{tabular}

persegi empat panjang pada bagian dinding sebelah kanan dan kiri terbuat dari batu bata, pada bagian depan terdapat beberapa buah jendela dengan ukuran besar, terdapat sebuah pintu pada bagian depan bahan pintu dan jendela terbuat dari kayu besi, pada bagian depan rumah tidak terdapat ornamen atau hiasan yang membedakan bangunan rumah tersebut dengan bangunan tempat tinggal penduduk di sekitarnya.

Bagian dalam terdapat ruang tamu yang sangat luas, ruangan ini berfungsi untuk menerima kunjungan para tamu dan sebagai ruang pertemuan raja dengan para bawahannya yang berada di kampung-kampung untuk membicarakan hal-hal yang dianggap penting. Bagian dalam ruang tamu terdapat kamar-kamar tidak ada pembagian khusus untuk menempatkan posisi kamar raja.

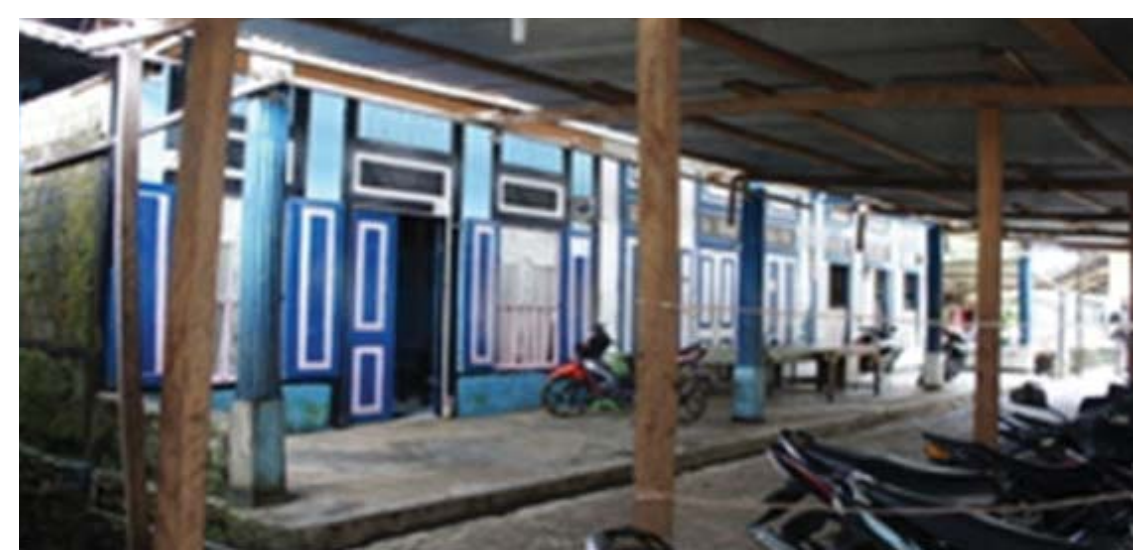

Foto 4. Bangunan tempat tinggal raja (dok. Balar Jayapura)

Sebelah barat masjid Jami terdapat kompleks makam keluarga raja Fatagar, terletak di Jalan Veteran dengan arah hadap utara selatan. Selain makam keluarga raja Fatagar dalam kompleks makam tersebut juga dimakamkan masyarakat umum yang tinggal di sekitar lokasi tersebut.

Bangunan masjid, bedug, makam keluarga raja ati-ati terdapat di Kampung Werpigan. Masjid berbentuk persegi empat arah hadap ke timur. Masjid dibangun pada tahun 1931 oleh raja ke-9 mengalami beberapa kali renovasi yang meliputi perluasan dan menghilangkan tembok yang asli, sebagian konstruksinya diganti sehingga tidak nampak bangunan yang asli, bangunan masjid terakhir kali direnovasi pada tahun 1991 . 


\begin{tabular}{|c|}
\hline Bau Mene \\
Masuknya Islam di Kabupaten Fakfak \\
\hline
\end{tabular}

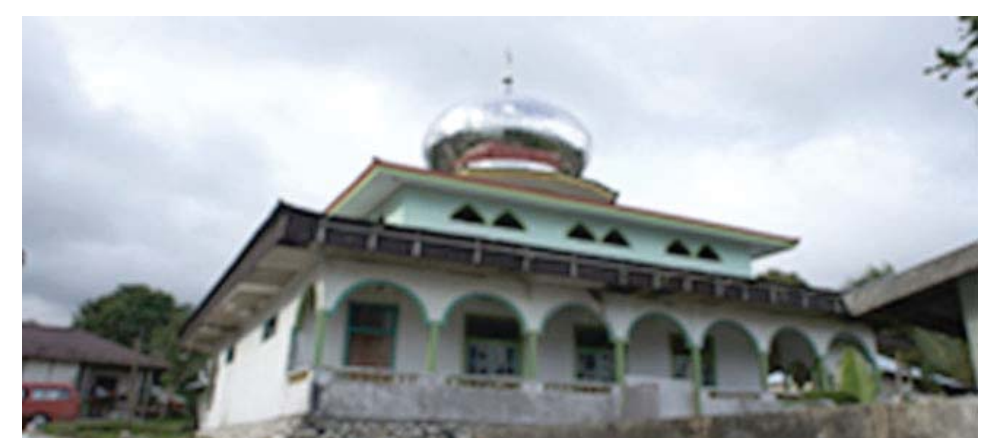

Foto 5. Masjid Werpigan (dok. Balar Jayapura)

Sebelah kanan masjid terdapat bedug. Bedug berbentuk bulat terbuat dari kayu pada bagian atas sebagai bidang pukul ditutupi dengan kulit binatang, ukuran tinggi 63 $\mathrm{cm}$, diameter bagian atas $97 \mathrm{~cm}$, diameter bagian tengah $82 \mathrm{~cm}$ pada bagian tengah dan bagian bawah terdapat ukiran motif bunga.

Sebelah barat masjid terdapat makam keluarga raja Ati-ati, makam dikelilingi pagar tembok. Nisan diganti dengan nisan baru karena nisan yang lama sudah rusak, terbuat dari kayu. Pada bagian sebelah barat mesjid kurang lebih $2 \mathrm{~km}$ terdapat tanah bekas bangunan Surau yang pertama didirikan oleh raja Ati-ati. Tanah tersebut berada di dekat pantai tidak terdapat sisa-sisa bangunan karena surau yang pertama dibangun terbuat dari kayu yang mudah rusak, yang ditemukan adalah bekas tanah dan batubatu yang digunakan sebagai tiang penyangga. Bangunan surau tersebut diperkirakan berbentuk panggung dan batu-batu disusun digunakan sebagai tiang penyangga.

Sebelah selatan masjid terdapat tanah bekas tempat tinggal raja, sekarang sudah dibangun rumah baru yang ditempati oleh keluarga raja Ati-ati, bentuk rumah yang asli sudah tidak dapat diketahui karena tidak terdapat bangunan ataupun sisa-sisa bangunan yang dapat kita lihat. Selain bangunan ada beberapa benda tinggalana raja Ati-ati yaitu Alquran dengan ukuran panjang $20 \mathrm{~cm}$, lebar 13,5 cm tebal $5 \mathrm{~cm}$ sampulnya dari kulit bintang, pada bagian dalam sampul terdapat tulisan angka tahun 1891 dengan tulisan tangan bahan terbuat dari kertas. 


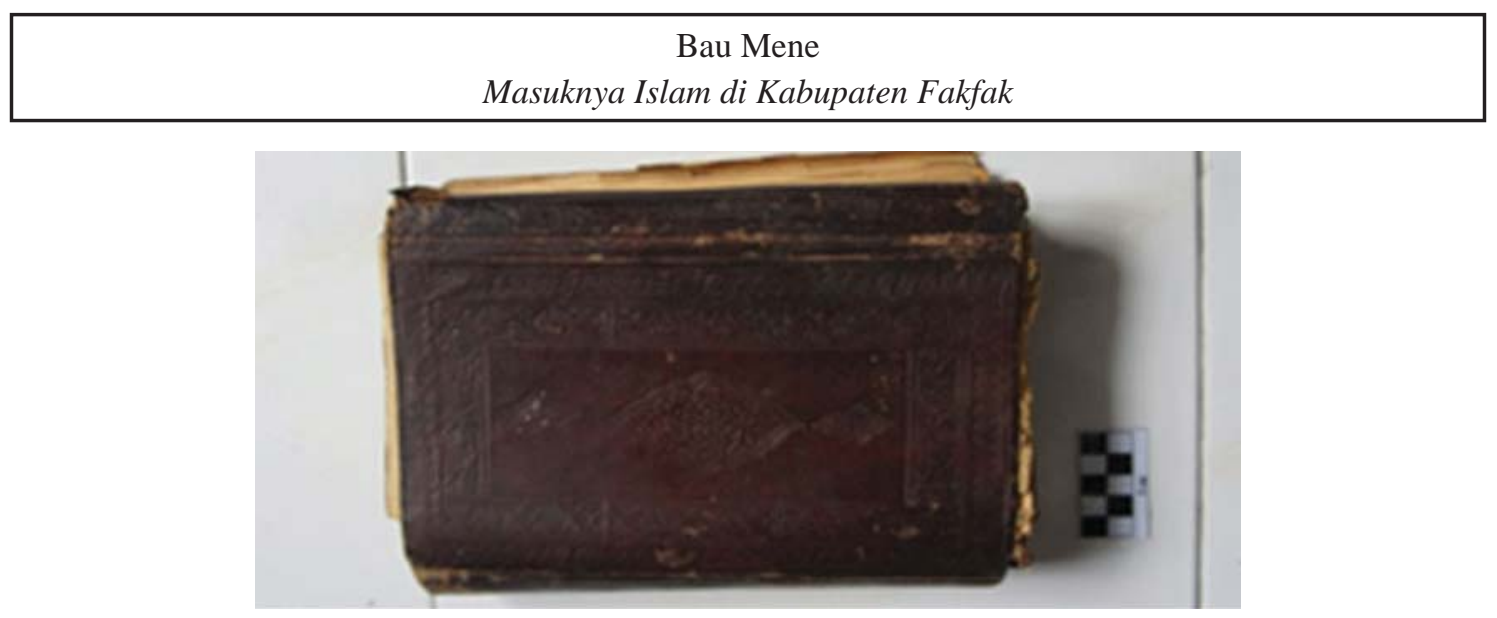

Foto 6. Alquran tinggalan raja Ati-ati

\section{Sejarah masuknya Islam di Kabupaten Fakfak}

Sejumlah catatan dari sejumlah pertuanan (kepemimpinan) raja-raja Fak-fak dapat dikemukakan yang menunjukkan keberadaan komunitas umat masa lampau di kawasan tersebut. Keterangan Raja Wertuar X, disebutkan bahwa pada masa pemerintahan raja Wertuar VI dan Ketujuh, dibangun masjid pertama Kerajaan Wertuar yang terletak di Patimburak pada tahun 1870, tetapi sudah ada bangunan musholla sebagai tempat ibadah mereka di tempat yang berbeda. Data silsilah menunjukkan bahwa raja Wertuar ketiga, Waney bertahta di Kramomongga sekitar tahun 1576-1646.

Diperkirakan bahwa agama Islam sudah ada dan berkembang di daerah Rumbati sebelum tahun 1724 dapat dibuktikan dengan ditemukan puing-puing bekas reruntuhan masjid. Dari keterangan Raja Rumbati ke-16 dikatakan bahwa Islam masuk di Was pada tahun 1506 melalui perang besar antara Armada Kesultanan Tidore yang dipimpin Arfan dengan kerajaan Rumbati.

Catatan pribadi Ibrahim Bauw, Raja Rumbati dijelaskan bahwa agama Islam telah masuk ke Semenanjung Onim Fak-fak pada tahun 1502 (Athwa, 2004, 45-47). Berdasarkan letak geografis diperkirakan bahwa agama Islam masuk ke wilayah Fakfak berasal dari Ternate dan Tidore yang mana pada waktu itu kerajaan Ternate dan Tidore yang memegang peranan penting dalam perdagangan maupun dalam proses penyebaran agama Islam di wilayah Semenanjung Onin dan kawasan Kepala Burung. Selain faktor geografis tersebut dapat kita lihat juga dengan adanya persamaan dalam pemberian gelar untuk para bawahan raja yaitu sangaji, kapitan, mayor dan lain-lain. 


\begin{tabular}{c|}
\hline Bau Mene \\
Masuknya Islam di Kabupaten Fakfak \\
\hline
\end{tabular}

Secara garis besar proses penyebaran agama Islam di wilayah Fakfak melalui beberapa jalur diantaranya:

1. Perdagangan. Para pedagang datang dan memperkenalkan ajaran agama Islam dengan menetap di berbagai pemukiman masyarakat di sekitar daerah pesisir pantai Semenanjung Onin, para pedagang selain berdagang mereka memperkenalkan agama Islam dengan jalan mengajar penduduk untuk melakukan sholat. Mereka mengikat hubungan baik dengan penduduk setempat dengan demikian mereka memperoleh akses yang memungkinkan mereka melakukan dakwah.

2. Politik. Yang dimaksud penyebaran dakwah melalui saluran politik, bahwa atas jasa dan upaya-upaya para raja dari kesembilan pertuanan dan keluargakeluarganya agama Islam turut disebarkan

3. Perkawinan. Para pedagang pada umumnya menempuh cara perkawinan agar lebih gampang atau mudah memperoleh kemungkinan dan jalan masuk untuk mendapatkan hasil pala dari masyarakat Fakfak.

4. Pendidikan non formal. Penyebaran dengan cara pendidikan non formal dilakukan melalui pusat-pusat pengajian yang berlokasi di masjid-masjid maupun di rumah para mubaliqh dan tentunya juga dilakukan di rumahrumah para raja (Onim, 2006:102-104).

Dengan demikian bahwa penyebaran agama Islam di Kabupaten Fakfak selain dilakukan oleh para pedagang dan para mubaliqh juga dilakukan oleh para raja.

\section{Bentuk pola pemukiman}

Menyajikan gambaran mengenai tempat dan cara bermukim manusia masa lalu, bahkan sejak ribuan tahun lalu, bukanlah suatu upaya yang mudah. Selain masyarakat penghuninya sudah punah, sehingga tidak mungkin ditanyakan kepada mereka: apa, mengapa dan bagaimana mereka memilih lokasi dan menata permukiman, juga jejakjejak hunian yang ditinggalkan mereka hanya sebagian kecil yang terlacak oleh para arkeolog (Rangkuti, 2006: 329). 


\begin{tabular}{|c|}
\hline Bau Mene \\
Masuknya Islam di Kabupaten Fakfak \\
\hline
\end{tabular}

Jika diperhatikan, letak geografis kota-kota pusat kerajaan bercorak Islam pada umumnya di pesisir-pesisir dan di muara-muara sungai-sungai besar. Hal ini dapat kita lihat pada kerajaan Gowa-Makassar, Ternate, Demak, Samudra Pasai dan lain-lain. Kota-kota tersebut berfungsi pula sebagai kota pusat kerajaan yang bercorak maritim. Masyarakat kota pusat kerajaan maritim lebih menitikberatkan kehidupannya pada perdagangan yaitu suatu ciri yang erat berhubungan dengan kenyataan bahwa para pedagang lebih sesuai hidup dalam masyarakat kota bercorak maritim (Poesponegoro, 2008: 253).

Demikian halnya dengan kerajaan-kerajaan yang ada di Kabupaten Fakfak, pusat kota terletak di daerah pesisir dengan pola penempatan bangunan untuk tempat tinggal para raja dan pemukiman penduduk berada di daerah sekitar pantai. Di wilayah Fakfak raja-raja yang berkuasa tidak mengenal adanya keraton atau rumah khusus raja, para raja membuat bangunan tempat tinggal dengan sangat sederhana yang terbuat dari kayu demikian juga tempat tinggal untuk para pembantu raja mereka membuat rumah yang sangat sederhana para pembantu raja tersebut ditempatkan di kampung-kampung, para pembantu raja pada setiap kampung diberi gelar sangaji, mayor, kapitan dan lain-lain.

Lokasi pemukiman penduduk terpusat yakni mengelompok, rumah-rumah saling berdekatan atau bersusun dengan rumah lainnya, mengikuti bentuk jalan desa atau kampung. Pada awalnya pemukiman penduduk tersebar pada kampung-kampung, setelah agama Islam masuk dan didirikan masjid pada wilayah tersebut, penduduk yang menganut agama Islam berpindah ke lokasi yang terdapat masjid. Dilihat dari persebarannya maka dapat dikatakan bahwa pola pemukiman awal terletak pada dataran rendah yang dekat dengan pesisir

Dengan mengambil titik pusat pada bangunan masjid maka dapat dirunut pola pemukiman pada awal masuknya Islam yaitu bangunan rumah raja berada pada sebelah selatan masjid, makam raja maupun kerabat raja berada pada bagian sebelah barat masjid sedangkan pemukiman penduduk tersebar disekitar bangunan rumah raja.

Menurut Grunebaum, bagi seorang muslim, kota pada dasarnya adalah suatu pemukiman tempat menjalankan kewajiban agama dan sosialnya secara keseluruhan. Oleh karena itu, kota Islam mempunyai beberapa fokus dalam bentuk fisik, yakni: masjid jami, kediaman penguasa, pasar, dan hunian penduduk. Sebagai suatu sistem, kota Islam memperlihatkan karakter dasarnya, yakni: 


\begin{tabular}{c} 
Bau Mene \\
Masuknya Islam di Kabupaten Fakfak \\
\hline
\end{tabular}

1. Benteng sebagai subsistem pertahanan keamanan

2. Kediaman penguasa dan bangunan pemerintahan sebagai subsistem administrasi politik,

3. Masjid jamik dengan madrasahnya, serta pemakaman sebagai subsistem ideologi,

4. Pasar dan infrastruktur transportasi sebagai subsistem ekonomi, dan

5. Perkampungan yang pengelompokan atas dasar etnis, profesi, dan agama sebagai sub sistem sosial (Ambary, 2006: 185).

Jika kita mengacu pada pendapat Grubenaum karakter dasar kota Islam maka pada wilayah penelitian terdapat perbedaan dimana tidak terdapat benteng, pasar, madrasah, perkampungan berdasarkan pengelompokan etnis, profesi dan agama. Pada wilayah penelitian terdapat bangunan rumah tempat tinggal raja, mesjid dan pemakaman serta perkampungan penduduk ditempatkan pada satu lokasi yang sama. Perkampungan penduduk tidak berdasarkan pengelompokan etnis, profesi dan agama semua penduduk berbaur menjadi satu dalam lokasi yang sama.

Masyarakat Jawa dalam kehidupan sehari-hari selalu berpedoman pada kepercayaan yang telah lama dianut secara turun temurun. Kepercayaan tersebut di antaranya tercermin pada aturan pembangunan rumah, dimana hanya masyarakat tingkat tertentu yang boleh membangun rumah dengan penampilan tertentu pula. Rumah berbentuk panggung pe dan kampung, adalah merupakan bentuk yang paling sederhana yang banyak dimiliki golongan rakyat biasa yang kurang mampu (Widyastuti, 2006, 268-274).

Berbeda dengan bangunan rumah tempat tinggal raja yang ditemukan di wilayah Fakfak dimana bangunan rumah tempat tinggal raja atau penguasa terbuat dari kayu dengan bentuk yang sangat sederhana tidak terdapat ornamen atau hiasan ataupun bentuk-bentuk khusus yang memperlihatkan bahwa bangunan tersebut adalah rumah seorang raja atau penguasa.

Dalam hal penempatan bangunan tidak ada pola aturan tertentu yang menyangkut pola tata letak rumah, bangunan rumah-rumah penduduk dan bangunan rumah raja dibangun pada lokasi yang sama bahkan berdekatan sehingga tidak nampak adanya perbedaan status sosial. Pada masyarakat di luar Papua bangunan tempat 


\begin{tabular}{|c|}
\hline Bau Mene \\
Masuknya Islam di Kabupaten Fakfak \\
\hline
\end{tabular}

tinggal raja maupun bawahan-bawahan raja ditempatkan pada lokasi yang berdekatan dan biasanya dikelilingi oleh pagar tembok bentuk bangunan berbeda dari rakyat biasa sedangkan untuk pemukiman penduduk biasa diletakkan agak jauh terpisah dari bangunan tempat tinggal raja dan bawahan-bawahannya.

Perbedaan lainnya nampak pada bangunan makam. Makam sebagai tempat kediaman terakhir dan abadi bagi manusia biasanya diusahakan oleh ahli warisnya untuk mendapatkan perlakuan seperti sewaktu masih hidup, lebih-lebih makam seorang raja dimana bentuk, susunan, hiasan, bahkan letaknya harus dibedakan dari rakyat biasa (Hadimulyono,1977:3 dalam Mene, 1998: 7) hal ini dapat kita temukan pada beberapa kompleks makam raja-raja di Sulawesi Selatan dan beberapa daerah lain dimana bentuk nisan maupun bentuk dan penempatan makam raja dibedakan dari rakyat biasa. Sehingga dalam penempatan makam nampak status sosial yang dimakamkan.

Penempatan makam pada tempat yang berbeda dengan rakyat biasa maupun perlakuan istimewa terhadap makam raja-raja, tidak dapat kita saksikan pada makam raja-raja yang ada di Kabupaten Fakfak, penempatan makam maupun penggunaan nisan pada makam raja-raja di Kabupaten Fakfak sangat sederhana dimana nisan menggunakan kayu sedangkan pada sekeliling makam tidak menggunakan jirat dan cungkup demikian halnya dengan makam rakyat biasa, dengan demikian tidak dapat dibedakan antara makam rakyat biasa dengan makam para raja ataupun kerabatnya.

Dengan demikian dapat dikatakan bahwa bentuk pola pemukiman awal masuk dan berkembangnya agama Islam pada wilayah Fakfak adalah pola pemukiman memusat yang mana antara bangunan rumah tempat tinggal raja, mesjid, makam keluarga raja dan kerabat serta bangunan pemukiman penduduk ditempatkan pada lokasi yang sama dan saling berdekatan.

\section{Ciri-ciri pengaruh budaya luar pada tinggalan arkeologi}

Temuan berupa bangunan masjid dan bangunan bekas tempat tinggal rumah raja dan makam para raja dan keluarga maka ada beberapa yang menunjukkan adanya pengaruh budaya luar. Bangunan tempat tinggal raja dapat dikatakan bahwa bangunan tersebut tidak menunjukkan adanya pengaruh budaya luar. Hal ini dapat diperlihatkan dengan bentuk bangunan yang sangat sederhana terbuat dari kayu besi dengan tidak 


\begin{tabular}{|c|}
\hline Bau Mene \\
Masuknya Islam di Kabupaten Fakfak \\
\hline
\end{tabular}

terdapat ornamen atau hiasan pada bagian dinding rumah yang menunjukkan bahwa hiasan tersebut adalah pengaruh budaya luar.

Demikian halnya dengan bentuk-bentuk nisan yang terdapat pada kompleks makam tersebut diperkirakan tidak mendapat pengaruh dari luar dimana nisannisan yang digunakan sangat sederhana tidak terdapat ornamen atau hiasan yang menunjukkan pengaruh budaya luar. Jika dilihat pada bangunan-bangunan keraton yang terdapat di Pulau Jawa, dimana bangunan-bangunan tersebut menghadap ke utara, maka di Fakfak bangunan raja yang masih ada sekarang juga menghadap ke utara dan diperkirakan juga bangunan-bangunan rumah raja lainnya juga menghadap ke utara yang mana pada bekas-bekas bangunan tersebut berdiri bangunan baru dan bangunan tersebut menghadap ke utara. Diperkirakan bangunan rumah raja menghadap ke arah utara

Pada bangunan masjid Merapi dapat dikatakan bahwa konstruksi bangunan masjid tersebut mendapat pengaruh budaya luar. Hal ini nampak pada bagian atap yang berbentuk atap tumpang tiga. Ciri-ciri masjid dengan konstruksi atap tumpang tiga dapat ditemukan pada bangunan-bangunan masjid yang pada di Jawa yaitu pada masjid Menara Kudus, masjid Demak, masjid Jepara, yang mana ciri-ciri bentuk atap tersebut diduga kuat berasal dari pengaruh Hindu.

\section{Simpulan}

Proses masuknya agama Islam di wilayah Kabupaten Fakfak berasal dari Ternate dan Tidore hal ini dapat kita lihat berdasarkan letak geografis yang mana wilayah Fakfak berdekatan dengan wilayah Ternate dan Tidore selain itu Ternate dan Tidore memegang peranan penting dalam perdagangan dan penyebaran agama Islam di sekitar wilayah kawasan Kepala Burung, dan Semenanjung Onin.

Bentuk-bentuk pemukiman awal masuknya Islam di wilayah Fakfak adalah pola memusat, bangunan-bangunan seperti masjid, rumah tempat tinggal raja, pemakaman raja dan kerabatnya serta pemukiman penduduk terletak pada wilayah pesisir. Tidak ada pola atau aturan dalam hal penempatan bangunan rumah, sehingga rumah tempat tinggal raja dan pemukiman penduduk letaknya saling berdekatan 


\begin{tabular}{c} 
Bau Mene \\
Masuknya Islam di Kabupaten Fakfak \\
\hline
\end{tabular}

Pengaruh budaya luar pada tinggalan arkeologi yang ditemukan dapat disaksikan pada bangunan masjid Merapi, atap berbentuk tumpang tiga diperkirakan bentuk atap mendapat pengaruh dari masjid di Pulau Jawa seperti masjid Menara Kudus, masjid Demak, masjid Jepara dan lain-lain.

\section{DAFTAR PUSTAKA}

Ambary, Hasan Muarif. 2006. "Kota-kota Islam“ dalam Permukiman di Indonesia Perspektif Arkeologi. Jakarta: Badan Pengembangan Sumberdaya Kebudayaan dan Pariwisata.

Athwa, Ali. 2004. Islam atau Kristenkah Agama Orang Irian?. Jakarta: Pustaka Da’i.

Mene, Bau. 1998. Nisan Arca pada Situs Makam Kuno Manuba di Kecamatan Mallusetasi Kabupaten Barru dan Makam Kuno Binamu di Kecamatan Tamalate Kabupaten Jeneponto Suatu Studi Perbandingan. Skripsi Jurusan Arkeologi Universitas Hasanuddin

Onim, J.F. 2006. Islam dan Kristen di Tanah Papua. Bandung: Jurnal Info Media.

Rangkuti, Nurhadi. 2006. “Kearifan Dalam keragaman” dalam Permukiman di Indonesia Perspektif Arkeologi. Jakarta: Badan Pengembangan Sumberdaya Kebudayaan dan Pariwisata.

Siswanto, Joko. 2009. "Kajian Permukiman di Situs Utelemu Berdasarkan Data Artefaktual” dalam Jejak-Jejak Arkeologi. Balai Arkeologi Manado.

Poesponegoro, Marwati D. 2008. “Sejarah Nasional Indonesia III Zaman Pertumbuhan dan perkembangan Kerajaan Islam di Indonesia” Jakarta: Balai Pustaka.

Tim Peneliti. 1996/1997. "Laporan Penelitian Arkeologi Islam di Kecamatan Kokas Kabupaten Fakfak Irian Jaya”. Laporan penelitian Balai Arkeologi Jayapura.

Tim Peneliti. 1999. "Laporan Penelitian Arkeologi Islam di Kecamatan Fakfak Kabupaten Fakfak Irian Jaya “, Balai Arkeologi Jayapura.

Widyastuti, Endang. 2006. “Rumah-Rumah Pangeran di Yogyakarta” dalam Permukiman di Indonesia Perspektif Arkeologi. Jakarta: Badan Pengembangan Kebudayaan dan Pariwisata. 